\title{
Reproductive human rights: General legal support and implementation in the field of criminal justice
}

\author{
Ivan Titko* and Inna Polkhovska \\ Poltava Law Institute of Yaroslav Mudryi National Law University, Poltava, Ukraine
}

\begin{abstract}
The unsatisfactory demographic situation in European countries, in particular the reduction of fertility, actualizes the issue of reproductive rights. Reproductive rights include the human ability to make free and independent decisions about their reproductive health, including the birth of children, the time and intervals between their birth, the right to decide on procreation without discrimination, threats and violence, as well as recognition of the right to receive relevant information. The article is devoted to the analysis of some problematic general theoretic, criminal law and criminal procedure aspects in the field of reproductive rights. In particular, issues of assisted reproductive technologies application, their regulation at the international and national levels, as well as in the practice of the European Court of Human Rights (hereinafter - ECHR) are considered in the article. Special attention is paid to the specificity of the legal and practical factors of surrogacy.
\end{abstract}

Key words: reproductive right, assisted reproductive technologies, artificial insemination, surrogacy, reproductive factors in criminal law, reproductive factors in criminal process, reproductive rights and criminal justice.

\section{Introduction}

The development of new technologies in the field of biomedicine is due to unsatisfactory demographic situation, since mortality rates exceed fertility rates in most European countries. This is a matter of extreme significance since the society's sustainable development of any country depends on its demographic prospect, which is directly related to the reproductive health of the nation. Confirmation of the relevance of this issue is the inclusion of reproductive health and reproductive right issues under UN Sustainable Development Goals (2015) [1]. In its turn, the specified program direction, declared by the UN, cannot be implemented without proper normative regulation of the issue of reproductive rights at the level of national legislation of individual countries. In addition, due to the transnational nature of specific issues in this area, proper regulation of issues at the level of international acts aimed at synchronizing the laws of individual states is also necessary. It should be noted separately that the issue of reproductive rights is complex. The regulation and protection of these rights are carried out not only by the constitutional, civil and specialized health legislation, but also by the criminal and criminal procedure legislation. However, the imperfection of international and national legislation somewhere in the settlement gap of certain issues in the field of

\footnotetext{
* Corresponding author: titko.iv@gmail.com
} 
reproductive right causes conflicts and practical problems. All this determines the need for a scientific study of this issue.

\section{Aim}

The aim of the study is to obtain results in the form of a set of scientific conclusions, regarding the specifics of legal provision of reproductive rights, problems and possible solutions in this area. The aim determines the need for a solution of the following tasks of the research: to analyze international acts, national legislation of individual countries, as well as the practice of the ECHR to ensure reproductive rights; to identify directions and protection peculiarities of reproductive human rights in the field of criminal justice; to identify problems caused by the legal regulation disadvantages of certain types of reproductive rights; to formulate conclusions and suggestions aimed at overcoming the problems identified.

\section{Material and methods}

While preparing this work, the following sources were used: World Health Organization (hereinafter - WHO) statistical data, international normative legal acts, internal law and judicial practice of individual states, practice of the ECHR (from the official website of the ECHR and other available databases). To reach the aim of the research, a set of general scientific and special methods that are traditional for legal science was used (in particular historical, logical, statistical, and comparative legal methods of research).

\section{Results and discussion}

One of the most pressing issues of biomedical ethics today is the development of reproductive technologies, in particular the so-called assisted reproductive technologies. Assisted reproductive technologies (hereinafter - ART) are methods of infertility treatment, in which manipulations with reproductive cells, some or all stages of the reproductive cells preparation, fertilization processes and development of embryos for transferring them into the patient's uterus are carried out in vitro (the technique of experiment or other manipulations conducted in a special laboratory glassware or in a controlled environment outside the living organism). According to the WHO, $15 \%$ of reproductive age couples in the world suffer from infertility [2]. ART allow to solve tasks related to fertilization of the egg cell in a woman's body or outside it, prenatal sex selection, genetic purification of the population, preservation (freezing) of the genetic material, cloning, foetal and use of stem cells and tissues of the embryo and foetus, storage of umbilical cord blood, etc.

According to R. Stefanchuk, the system of reproductive rights as personal non-property rights of an individual should include: the right to reproductive choice; the right to reproductive health; the right to information about reproductive rights; the right to the privacy of reproductive rights realization; the right to protection of reproductive rights [3].

Some states have chosen the reproductive right's regulation at the level of law. In particular, certain laws have been adopted: On the Protection of Reproductive Health and Family Planning (the Republic of Moldova, May 24, 2001), On Sexual and Reproductive Health (the Republic of Latvia, January 31, 2002), On Norms of Assisted Reproductive Technologies (the Italian Republic, February 19, 2004), On Assisted Reproductive Technologies (the Republic of Belarus, January 7, 2012), On the Reproductive Rights of Citizens and Guarantees of their Implementation (the Kyrgyz Republic, July 4, 2015), the law has been regulated artificial insemination in Poland since July 10, 2015, etc. 
But at the level of national legislation, it is mostly the by-laws that establish the rules for regulating the relations between patients (women, men) and health care institutions that ensure the application of assisted reproductive technology techniques and determine the mechanism and conditions for the use of assisted reproductive technologies. For example, in Ukraine, in the absence of a special law, the Order of the Ministry of Health of Ukraine On Approval of the Procedure for the Application of Assisted Reproductive Technologies in Ukraine of October 02, 2013 is in force. Such rules usually cover the medical aspect of the issue, and the legal aspects, due to the complexity of the specifics, remain neglected. In terms of legal regulation of ART, the way of dealing with infertility has a special difficulty. This is a surrogacy that is increasingly in demand, a practice in which a woman (called a surrogate mother) becomes pregnant and gives birth to a baby for the purpose of giving it to someone, who cannot have children. Two kinds of surrogacy are distinguished:

- gestational surrogacy (when a surrogate mother gives birth to the baby, but she is not its genetic mother). Gestational surrogacy is realized by artificial egg cell insemination of a future mother or donor;

- traditional surrogacy (when a surrogate mother is a biological and genetic mother of the baby). Traditional surrogacy can be realized by means of artificial insemination or by means of insemination: a surrogate mother provides the egg cell, and the semen is provided either by the father or by the donor [4].

For full understanding of the surrogacy phenomenon, its trends and frequencies, there are currently no reliable statistical data for a number of reasons. First of all, countries do not have a system for monitoring cases of surrogacy yet. Even if countries would try to carry out such monitoring, most likely it would not be possible to obtain accurate figures because of the existence of informal arrangements for surrogacy. In addition, taking into account social condemnation, and some parents and surrogate mothers are afraid of it, it is not surprising that it is not heard much about surrogacy from its participants. Finally, getting accurate figures will be difficult since many couples who choose to resort to surrogacy do not do it in the countries where they live [5].

The aforementioned problem of surrogacy latency complicates the regulation of this issue at the level of the legal field, which in its turn results in the use of surrogacy for trafficking in human beings or the performing illegal organ transplantation. In order to prevent such cases at the international level, a number of anti-trafficking agreements and commitments have been concluded, such as the Protocol to Prevent, Suppress and Punish Trafficking in Human Beings, especially women and children, supplementing the United Nations Convention against Transnational Organized Crime (2000), the OSCE Action Plan to Combat Trafficking in Human Beings (2003) and the Council of Europe Convention on Action against Trafficking in Human Beings (2005).

Existing policies and legislation regarding surrogacy can be divided into three main regimes that govern these issues. The altruistic regime under which the surrogacy is permitted by the state, but a surrogate mother receives compensation for expenses only for medical care and other expenses related to pregnancy. Future parents contracting with a surrogate mother are not allowed to pay for the service of pregnancy and childbirth. This approach is intended to avoid the transformation into a product a surrogate mother and a child (often considered to be a sale of children). The altruistic regime has been adopted in the following countries: Australia, Canada, the United Kingdom, the Netherlands, and Belgium.

Under the permissive regime, countries allow surrogacy at the legislative level with specific regulation of some aspects. Examples of countries: Georgia, India, the Russian Federation. However, there are some variations in the legal regime. For example, in Israel 
surrogacy is controlled by the state, that is, every step needs permission. In South Africa, a contract with a surrogate mother must be confirmed by the court.

Under the prohibiting regime, the conclusion of contracts on surrogacy is not allowed. Countries that have decided to adopt such a regime were guided by moral and ethical principles, such as avoiding the transformation of children into the goods and exploitation of surrogate mothers, as well as in order to protect their interests. These countries are France, Sweden, Hungary, Germany, Iceland, Italy, Japan, Switzerland, Pakistan, Saudi Arabia, and Serbia [5]. It was stated by the ECHR in the case of S. H. and Others v. Austria (2011) [6] that although there was a clear tendency in Europe to increase the proportion of gametes donors for IVF, such a consensus was not based on established legal principles.

Given this, there is a common practice for married couples or single parents, homosexual or lesbian couples from the countries with prohibiting regime to travel to countries with permissive jurisdiction to receive appropriate services. Even living in countries where surrogacy is permitted by law, parents can decide to go to the country where anonymous use of donor gametes is possible. However, there is a risk of non-recognition of the relevant documents (as well as the parent-child relationship) associated with the childbirth in the country of their citizenship or permanent residence. This has a direct negative impact on the fate of a newborn child. By the way, in Ukraine, nobody checks whether the child's parents can legitimize their own status in the country of their nationality, and there are no risks for the child if the parents refuse the child for some reason, that is, the rights of the child born by a surrogate mother in Ukraine are not protected at all. According to the Law of Ukraine On Citizenship of Ukraine, a child has the right to be a citizen on the principle of the right of soil, that is, as having acquired the citizenship of Ukraine on the fact of birth on the territory of the state regardless of the parents' nationality (Art. 7).

In 2011, the story of the French couple got a certain resonance. Patrice Le Roch, the father of children born by Ukrainian surrogate mother, tried to take them illegally from Ukraine to France. This was preceded by the refusal of the embassy of this country to grant them citizenship and give out all the necessary documents. Ukrainian border guards found children during the inspection of a minibus which Mr. Le Roch drove. The Transcarpathian court imposed a French citizen a fine for attempting to illegally cross the border and ordered the vehicle to be confiscated. Ukrainian judges did not dare to punish the father for such a desperate step more strictly. In the end, having stayed in Ukraine for more than six months, Patrice Le Roch received Ukrainian citizenship for them, and he was able to leave the country with them [7].

For example, in order to become official parents of a baby born by a surrogate mother, British couples should receive a parental order from the court. At the same time they are obliged to prove that they have reimbursed all expenses of the woman who was carrying their child. In other words, a surrogate mother should legally receive not fee, but compensation. This is due to the fact that in the UK only altruistic surrogacy is allowed. Otherwise, the British court will have every reason not to recognize biological parents. As a result, a collision occurs [8].

According to Ukrainian legislation, in this situation a surrogate mother will not have any rights to the baby; the foreigners will be recognized as its father and mother. And according to British legislation, the latter will not have parental rights, and the woman will be considered a mother of the baby, who has signed consent to its transfer to foreigners. As a result, the child will have no citizenship or legal parents under the laws of the United Kingdom. In 2008, the London Court considered a similar case and made a decision "in the best interests of the child"; it recognized the British parents, taking into account all their personal circumstances [8]. 
This issue is also reflected in the judgment of the ECHR: Menneson v. France (2014) [9], D. and Others v. Belgium (2014) [10], Paradiso and Campanelli v. Italy (2017) [11], Laborie and Others v. France (2015) [12], Foulon and Bouvet v. France (2016) [13], and others. In particular, in cases of Menneson v. France and Paradiso and Campanelli v. Italy, the court found that the authorities were unlawful in refusing to recognize individuals as children's parents, although the parental ties had been lawfully established in the country of the childbirth. In such cases, the Court first of all tries to protect the interests of the child and the right of individuals to family life.

The cost of services is another important factor. In the US, a country where surrogacy is allowed in 16 states, the cost of surrogacy is estimated between $\$ 59,000$ and $\$ 80,000$, while in India the cost is between $\$ 10,000$ and $\$ 35,000$ [5]. For example, in Ukraine, even in public transport, you can see the ads of surrogacy services with the corresponding price offers (which are significantly lower than abroad and vary between $\$ 20,000$ and $\$ 25,000$ ), not mentioning the distribution of such information on the Internet. The authors of such advertising assure the full legality of such actions and refer to the Civil Code of Ukraine, in particular Art. 290, that an adult capable and active natural person has the right to be a donor of blood, its components, as well as organs and other anatomical materials and reproductive cells. Taking into account the difficult financial situation of a significant part of Ukrainians, advertisements like this are in demand. For example, the Italian law provides an imprisonment for a term from three months to two years and a fine of up to EUR 1 million for individuals who in any way advertise donations and surrogacy in Italy. In this case, the Italians are not prohibited to use such services abroad [14].

In other words, there is a situation where using surrogate mother services, for example, in Ukraine is much easier than going through the child adoption process, especially when it concerns foreigners. This is due not to the permissive regime, but superficial legislative regulation. After all, the problem can get much deeper looking at it from the moral and ethical side while trying to take into account the interests of a future child. The surrogate mother, according to the Ukrainian law, has no rights to the child. However, according to the laws of countries where surrogacy is prohibited or allowed only as non-commercial assistance, it is she who is a rightful mother, unless the court decides in favour of biological parents. In Ukraine, there is no control and verification of documentation provided by foreign married couples. In the future, the law should necessarily include a monitoring mechanism to verify whether future parents are able to legalize their own and their children's status in their own country.

At present, the current constitutional legislation of Ukraine and many countries does not recognize the embryo as a subject of legal relations. That is, the starting point for a person's right to life is the moment of physiological birth, not conceiving. The ECHR in the case of Evans v. the United Kingdom (2007) adhered to an opinion when it recognized that created embryos did not have the right to life and their destruction did not violate the provisions of the Convention [15]. In the case of Vo v. France (2004), the court continued its opinion and ruled that it was not desirable or impossible to decide whether an unborn child is a person under Art. 2 of the Convention [16]. In the case of Parrillo v. Italy (2015), the Court noted that since embryos contain the applicant's genetic material, they were an integral part of her personality [17].

It should be noted that the systematic approach to normative assurance of reproductive rights is quite significant. In addition to the general legal aspects (which are embodied at the level of the Constitution, civil law and specialized sector laws), the systematic approach implies the need to remember that other areas of legislation can also largely relate to reproductive rights. In particular, we consider this thesis on the example of criminal and criminal procedure law. 
By studying the criminal law sector, we support the opinion of K.V. Diadiun, who offers to distinguish two aspects in the protection of the reproductive sphere: a) the regulation of criminal responsibility for criminal acts related to reproductive aspects; b) humanization of responsibility and mitigation of punishment in view of reproductive peculiarities [18]. The first aspect, which reveals protective function of criminal law, is connected with the consolidation of socially dangerous violations of reproductive rights as criminal offenses, the commission of which will serve as the basis of criminal liability. For example, the criminal laws of different states provide responsibility for:

- breach of professional duties during the termination of pregnancy ( $\$ 218 \mathrm{c}$ of the Criminal Code of the Federal Republic of Germany), abortion without medical advice ( $\$ 218 b)$, agitation for abortion ( $\$ 219 a)$, sale of means for abortion $(\S 219 \mathrm{~b})$;

- collection or removal of gametes of a living person without his/her written consent (Art. 511-6), information disclosure about the couple who provided gametes, and the couple who received them (Art. 511-10), the collection or removal of gametes from a living person without carrying out necessary tests for infectious diseases (Art. 51111), illegal artificial insemination (Art. 511-12), illegal actions with a human embryo (Chapter I Section I Book V of the French Criminal Code: Art. 511-15-511-25-1);

- abortion without the consent of a woman (Art. 144 of the Criminal Code of Spain) or with her consent in cases of unforeseen law (Art. 145), the abortion of pregnancy with gross negligence (Art. 146), intentional (Art. 157) or negligent (Art. 158) damage to the foetus, fertilization of the human egg cell with another purpose, not reproduction (Part 1, Art. 161), the use of artificial insemination without the woman's consent (Art. 162);

- carrying out artificial insemination without the woman's consent or in spite of it (Art. 214 of the Criminal Code of the Portuguese Republic);

- pregnancy termination by the woman (Part 3 Art. $118^{1} 2$ of the Criminal Code of the Swiss Confederation) or another person (Part 1, 2 Art. $118^{1} 2$ ), the unlawful pregnancy termination by a doctor or failure to report this to a competent health authority (Art. 12012);

- abortion by the woman herself or assistance in doing it (Art. 152 of the Criminal Code of the Republic of Poland), termination of pregnancy without the consent of a woman with the use of violence, threats or deception (Art. 153), while the qualifying feature is abortion with respect to the foetus, which can independently live beyond the maternal organism ( $\$ 3$ Art. 152, $\S 2$ Art. 153), abortion, which caused the death of a pregnant woman (Art. 145);

- illegal abortion (Section 4 of the Criminal Code of the Republic of Estonia): abusive abortion without consent of the pregnant woman ( $\$ 125)$, unauthorized abortion ( $\S$ 126), abortion with violation of permissible terms ( $\$ 127)$, granting consent to unlawful termination of pregnancy ( $\$ 128$ ); the illegal handling of human embryos (Section 5): damage to the human embryo ( $\S 129)$, the implementation of prohibited operations with embryos ( $(130)$, abusing the creation of human embryos ( $\$ 131)$, illegal surrogate motherhood (\$132);

- the abortion (Art. 153 of the Criminal Code of the Republic of San Marino), the artificial insemination of a married woman without the husband's consent (Art. 226) or through the use of violence, threats or deception (Art. 277);

- abortion by a woman on her own (Art. 222 of the Criminal Code of the Japanese State), abortion with the consent of the victim which caused death or bodily harm (Art. 213), an abortion by a medical worker (a doctor, an obstetrician, a pharmacist) (Art. 214); an abortion without the consent of the pregnant woman (Art. 215) and one that caused death or bodily harm (Art. 216) [for more details: [19, 20]. 
The second aspect finds its expression in the following. In the criminal law of most modern states (in particular, in the legislation of Ukraine, the Republic of Belarus, the Russian Federation, the Republic of Latvia, etc.), reproductive factors in those or other variations are taken into account in the following cases: a ban assignment of certain types of punishment (as a rule, it refers to public works, corrective work, arrest, life imprisonment); taking pregnancy as a mitigating circumstance; considering the fact that the offender was aware of the victim's pregnancy as an aggravating circumstance; considering the fact that the offender was aware of the victim's pregnancy as a qualifying attribute; considering reproductive factors when establishing criminal law in a privileged form for certain acts (for example, responsibility for illegal abortion, a murder of her newborn child committed by the mother, etc.).

It is noteworthy that the controversial reproductive rights issues in the criminal law area have repeatedly been the subject of consideration by the ECHR. Thus, the ECHR commented on the possibility of sentenced prisoners to use assisted reproductive technologies [21]; the responsibility for the medical error that led to the abortion and loss of the foetus [16]; the criminalization of abortion and the right to abortion on medical indications [22]. We should note that, given the importance of reproductive rights role in the formation of the criminal law of the state, nowadays there is a position on the expediency of isolating the reproductive sphere as a separate object of criminal law protection in the criminal law science [18].

It is significant that reproductive human rights are largely reflected in the sphere of normative regulation of criminal justice proceedings. In particular, pregnancy (and in some cases abortion and post-birth period) as a legal fact, according to the legislation of different states, matters for such criminal procedures as: determination of the valid reason for the absence of a person on the call of an investigator, prosecutor, court (Art. 138 of the Criminal Procedure Code of Ukraine); a forcible bringing to court (Art. 140 of the CPC of Ukraine, Art. 250 of the Criminal Procedure Law of the Republic of Latvia, Art. 199 of the CPC of the Republic of Moldova); deferral sentence execution (Art. 536 of the CPC of Ukraine, Art. 638 of the CPL of the Republic of Latvia, Art. 469 of the CPC of the Republic of Moldova); release from a sentence serving (Art. 537 of the CPL of the Republic of Latvia); obligatory forensic medical examination (Art. 195 of the CPL of the Republic of Latvia); application of a preventive measure in the form of taking into custody (Art. 273 of the CPL of the Republic of Latvia), etc.

At the same time, reproductive factors have a certain potential for development not only within the aforementioned criminal law branches. For example, the problematic aspects of the implementation of reproductive rights by the convicted person are clearly illustrated in the above-mentioned judgment of the ECHR in the case of Dickson v. the United Kingdom (December 04, 2007, application no. 44362/04). The convicted husband was denied in the procedure organization for the artificial insemination of his wife, given the lack of "exceptional circumstances" envisaged by the British penitentiary legislation, when such reproductive technologies can be applied. Thus, the authorized state body did not find such circumstances, even considering the marginal age (from the reproductive point of view) of his wife at the time of the projected release of her husband, which would otherwise make it impossible to give birth to the child. The Grand Chamber of the ECHR, after reviewing the Chamber's judgment, concluded that there had been a violation of Art. 8 of the Convention for the Protection of Human Rights and Fundamental Freedoms because of the non-compliance of the member state of the Council of Europe with a balance between private and public interests, while restricting the rights of the convicted person [21]. This judgment is of particular interest in terms of two aspects. Firstly, both the Chamber and the Grand Chamber touched upon the question of compatibility with the conventional standards, albeit an "indirect" but still punitive restriction of the rights of convicts (as in the given 
example, the restriction of a person deprived of the right to freedom of movement, the right to create family), that is a criminal law aspect [for more details: 23]. Secondly, the theoretical development and normative implementation of procedural and organizational measures aimed at ensuring the realization of reproductive rights of individuals convicted to imprisonment look promising.

\section{Conclusions}

1) Reproductive rights are the inalienable human rights that need to be properly regulated and protected. The right to use ART methods is an integral part of reproductive rights being implemented in order to protect reproductive health, infertility treatment, the right to procreation, preservation of reproductive material and embryos. 2) Modern civilization way of regulating relations in society and the state is their legal regulation. For proper protection of reproductive rights at the level of national legislation of certain states, in particular Ukraine, there should be a special law that would take into account the interests of a newborn child, including the rights and responsibilities of patients, the responsibility of the medical institution; the procedure for implementation of ART, in particular the legal aspects of surrogacy; protection of reproductive information, etc. 3) The specificity of reproductive rights is their so-called migratory nature, so it is important for universal standards in their settlement to be worked out by the international community. 4) An integrated approach to normative regulation of reproductive human rights obliges considering them as a legal fact in the field of criminal law and criminal procedure law relations. 5) The theoretical development and normative implementation of procedural and organizational measures aimed at ensuring the realization of reproductive rights of individuals convicted to imprisonment look promising.

\section{References}

[1] UN Sustainable Development Goals (2015). Retrieved from https : //www . un .org/ sustainabledevelopment/

[2] Mother or Nothing: The Agony of Infertility. Bulletin of the World Health Organization (2010). Retrieved from https://www. who.int/bulletin/volumes/ 88/12/10-011210/en/

[3] R. Stefanchuk, Reproductive Rights of an Individual: Concept, System, Peculiarities of Realization (2004). Retrieved from http: //radnuk. info/component/content/ article/24658

[4] A. Brashovianu, International Experience in Legislative Regulation of the Reproductive Technologies Use (Including Surrogacy), 60 (2013)

[5] E. Nelson, Global Trade and Assisted Reproductive Technologies: Regulatory Challenges in International Surrogacy. J Law Med Ethics. 41, 240-253 (2013). Retrieved from http://onlinelibrary.wiley.com/doi/10.1111/ jlme.12016/abstract

[6] Case of S.H. and Others v. Austria (Application no. 57813/00) (2011). Retrieved from http://hudoc.echr.coe.int/eng?i=001-107325

[7] Judgement of the Berehovo District Court of Zakarpattia Oblast, case no. 1-131/11/ (2011). Retrieved from http://www.reyestr.court.gov .ua/Review/15625789

[8] Threats of Surrogacy in Ukraine: Children without Parents and Citizenship (2018). Retrieved from http://argumentua.com/novosti/zagrozi-surogatnogomaterinstva-v-ukra-n-d-ti-bez-batk-v-gromadyanstva 
[9] Case of Mennesson v. France (Application no. 65192/11) (2014). Retrieved from http://hudoc. echr. coe.int/eng?i=001-145389

[10] Case of D. and Others v. Belgium (Application no. 29176/13) (2014). Retrieved from https://www. legal-tools.org/doc/05bc7c/pdf/

[11] Case of Paradiso and Campanelli v. Italy (Application no. 25358/12) (2017). Retrieved from http://hudoc.echr. coe.int/eng?i=001-170359

[12] Case of Laborie and Others v. France (Application no. 44024/13) (2017). Retrieved from http://www.bailii.org/eu/cases/ECHR/2017/74.html

[13] Case of Foulon and Bouvet v. France (Application no. 9063/14 and 10410/14) (2016). Retrieved from https://rm.coe.int/case-law-2017/1680736451

[14] Legislation of Italy in the Field of Assisted Reproductive Technologies. Retrieved from http://www.irtsa.com.ua/en/legislation/italy.html

[15] Case of Evans v. The United Kingdom (Application no. 6339/05) (2007). Retrieved from http: //hudoc.echr. coe.int/eng?i=001-80046

[16] Case of Vo v. France (Application no. 53924/00) (2004). Retrieved from http://hudoc.echr.coe.int/eng?i=001-61887

[17] Case of Parrillo v. Italy (Application no. 46470/11) (2015). Retrieved from http://hudoc.echr.coe.int/eng?i=001-157263

[18] K. Diadiun, Reproductive Sphere as an Object of Criminal Law Protection: Features of Liability Regulation, 198 (2016)

[19] A. Blinov, The Doctrine of Criminal Law Protection of the Patient's Rights and Freedoms (thesis for a Doctor's degree), 561 (2014)

[20] K. Cherevko, Criminal Legal Analysis of International Legislation on the Norm of Criminal Liability for Illegal Abortion. Law Forum. 3, 733-738 (2013). Retrieved from http://nbuv.gov.ua/UJRN/FP_index.htm_2013_3_120

[21] Case of Dickson v. The United Kingdom (Application no. 44362/04) (2007). Retrieved from http://hudoc.echr. coe.int/eng?i=001-83788

[22] Case of A, B AND C v. Ireland (Application no. 25579/05) (2010). Retrieved from http://hudoc.echr.coe.int/eng?i=001-102332

[23] V. Chovhan. Prisoners' Rights Restriction: Legal Nature and Justification, 608 (2017) 